\title{
REFORMA RYNKU CUKRU UNII EUROPEJSKIEJ I JEJ WPŁYW NA UPRAWE BURAKÓW CUKROWYCH I PRODUKCJĘ CUKRU W POLSCE
}

\section{THE EUROPEAN UNION SUGAR MARKET REFORM AND THE IMPACT ON THE PRODUCTION OF SUGAR BEET AND SUGAR IN POLAND}

\author{
Anna DUBOWNIK • Roman RUDNICKI \\ Uniwersytet Mikołaja Kopernika \\ Wydział Nauk o Ziemi, Katedra Gospodarki Przestrzennej i Turyzmu \\ ul. Lwowska 1, 87-100 Toruń \\ a_dubownik@umk.pl•rudnickir@umk.pl
}

\begin{abstract}
Zarys treści: W artykule przedstawiono wstępne wyniki badań przestrzennych dotyczących reformy rynku cukru Unii Europejskiej z 2006 roku. Przeanalizowano zagadnienie spadku powierzchni upraw buraków cukrowych w Polsce w latach 2002-2010. W badanych latach odnotowano także pozytywne zjawisko wzrostu plonów buraków cukrowych. Reforma rynku cukru oprócz ograniczenia limitów produkcji cukru, zakładała wprowadzenie płatności cukrowych, które miały spowodować ograniczenie produkcji surowca. Konsekwencją tego zjawiska była likwidacja zakładów cukrowniczych, które na wielu obszarach stanowiły znaczącego pracodawcę. W wyniku reformy musiał się zmienić profil produkcji plantatorów, ale również musiało nastąpić przekwalifikowanie ludności na rynku pracy. Istniejące cukrownie zarządzane przez spółki zarówno z kapitałem polskim, jak i niemieckim wykazują tendencję do kumulowania kapitału. Polska przynależy do tzw. „pasa buraczanego” Unii Europejskiej, czyli do zbioru krajów z największym potencjałem produkcji cukru. Nie jest jednak jasne, jak wspólny rynek i skutki kolejnej reformy w 2017 r. wpłyną na poziom konkurencyjności polskiego cukrownictwa.
\end{abstract}

Słowa kluczowe: reforma rynku cukru UE, buraki cukrowe, cukrownie, „pas buraczany” UE, Polska.

\section{Wstęp}

Rynek cukru w państwach Europejskiej Wspólnoty Gospodarczej i Unii Europejskiej jest regulowany od 1968 r. i zakłada przede wszystkim ochronę rynku wewnętrznego. Od 2004 r. system regulacji rynku cukru dotyczy także Polski. Przemysł cukrowniczy - mający wieloletnią tradycję - jest jedną z najważniejszych branż polskiego przemysłu rolno-spożywczego. W latach 1801-1802 w Konarach na Dolnym Śląsku wybudowano pierwszą na świecie cukrownię przerabiającą buraki cukrowe (Głębocki 2007, s. 235). Współczesne zmiany związane są z unijną reformą systemu regulacji rynku cukru w latach 2006-2010. Reforma 
ta zakładała koncentrację produkcji buraków cukrowych na obszarach charakteryzujących się najkorzystniejszymi warunkami glebowo-klimatycznymi oraz wzrost wydajności produkcji w pozostających cukrowniach.

Niniejsze opracowanie ma na celu prześledzenie zmian powierzchni i rozmieszczenia uprawy buraków cukrowych w Polsce w latach 2002-2010. Podjęto próbę określenia zależności między zmniejszającą się liczbą cukrowni a rozmieszczeniem i wydajnością upraw, zwłaszcza w kontekście systemu płatności cukrowych, które były głównym instrumentem badanej reformy.

Jako podstawowe jednostki analizy przestrzennej przyjęto 314 biur powiatowych ARiMR (por. Rudnicki 2009, s. 6-8). W celu pełniejszej oceny zróżnicowania przestrzennego w analizie uwzględniono cztery determinanty:

- przyrodniczą - na podstawie wskaźnika jakości rolniczej przestrzeni produkcyjnej (wjrpp), przyjmując kryteria dostępu do działania PROW „Wspieranie działalności rolniczej na obszarach o niekorzystnych warunkach gospodarowania” (ONW), wydzielono obszary o niekorzystnych (poniżej 52 pkt wjrpp - strefa nizinna), średniokorzystnych (52-72 pkt wjrpp - strefa nizinna) i korzystnych (wjrpp powyżej 72, poza płatnościami ONW) warunkach przyrodniczych;

- urbanizacyjną - wydzielono obszary: (1) słabo zurbanizowane (położone w obrębie podregionów przeważająco wiejskich), (2) przeciętnie zurbanizowane (położone w obrębie podregionów pośrednich) i (3) silnie zurbanizowane (położone w obrębie podregionów przeważająco miejskich; wg podziału Banku Danych Lokalnych GUS; por. tab. 1);

- historyczną - wydzielono obszary położone na terenach Polski w okresie międzywojennym, w tym dawnych zaborów austriackiego (1), pruskiego (2) i rosyjskiego (3) oraz w granicach dawnego zaboru pruskiego i na terytorium Niemiec w okresie międzywojennym (4);

- rolniczą, związaną z wydzieleniem szeregu cech diagnostycznych rolnictwa, a następnie - po ich normalizacji (Racine i Raymond 1977) - ujęciu ich w formie jednego syntetycznego wskaźnika informującego o niskim (poniżej 0,50 §), średnim

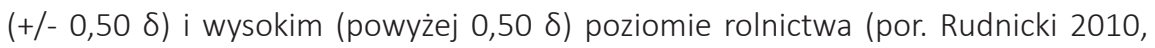
s. 54-57).

W artykule wykorzystano wyniki powszechnych spisów rolnych z lat 2002 i 2010 oraz dane Agencji Restrukturyzacji i Modernizacji Rolnictwa (ARiMR) dotyczące powierzchni objętej płatnościami cukrowymi w 2010 r.

Oprócz wyznaczenia wskaźników zmian powierzchni uprawy buraków cukrowych oraz liczby funkcjonujących cukrowni w badanych latach, w celu klasyfikacji powiatów o najkorzystniejszych warunkach rynkowych do produkcji buraków cukrowych w Polsce posłużono się metodą hierarchicznej analizy skupień Warda (Ward 1963). W celu oceny zróżnicowania przestrzennego reformy rynku cukru UE wprowadzono również do analizy zagadnienie relacji między powierzchnią zasiewów buraków cukrowych wg PSR 2010 a powierzchnią objętą płatnością cukrową wg ARiMR. 


\section{Polska w „pasie buraczanym” Unii Europejskiej}

Kraje Unii Europejskiej są w czołówce światowej w produkcji cukru z buraków cukrowych. W wyniku regulacji wewnętrznych doszło, wg raportów Światowej Organizacji Handlu (WTO), do destabilizacji globalnego rynku cukru. Chcąc uzdrowić sytuację, dokonano próby zreformowania rynku cukru w Unii Europejskiej oraz restrukturyzacji przemysłu cukrowniczego.

Przed reformą funkcjonowały na rynku unijnym ceny interwencyjne wyprodukowanego cukru oraz ceny minimalne (gwarantowane) skupu buraków cukrowych. Skala produkcji cukru była limitowana - kwotowana. Stosowano również refundacje, gdy przeznaczało się wyprodukowany cukier dla przemysłu chemicznego, by zwiększyć popyt wewnętrzny oraz skup interwencyjny nadwyżek cukru. Istniały także dopłaty do eksportu cukru w ramach określonej kwoty oraz obowiązek eksportu bez dopłat cukru, którego ilość przekraczała wyznaczony limit. Ponadto rynek unijny chroniły wysokie cła oraz kontyngenty importu cukru bez cła lub w warunkach obniżonych stawek celnych. Ważnym narzędziem było także limitowanie produkcji substytutów cukru izoglukozy i syropu insulinowego (Evaluation of Common Agricultural Policy... 2011).

Obszary charakteryzujące się najlepszymi warunkami glebowo-klimatycznymi do uprawy buraków cukrowych i najwyższą ich produkcją w UE tworzą tzw. „pas buraczany". Zalicza się do niego: Wielką Brytanię, Francję, Belgię, Holandię, Niemcy i Polskę. Wprowadzona w sezonie 2006/2007 reforma rynku cukru Unii Europejskiej dotyczyła głównie wymienionych krajów. Jej nadrzędnym celem była redukcja kwot produkcyjnych obejmująca 5,8 mln ton cukru z buraków cukrowych (z $17 \mathrm{mln}$ ton w 2006 r. do 11,2 mln ton w 2010 r.). W wyniku reformy, mającej trwać cztery sezony, ceny interwencyjne cukru zastąpiono cenami referencyjnymi, których wartość stopniowo obniżano, aż o 36\% do 2010 r. Obniżono także cenę minimalną skupu buraków cukrowych (z 32,6 euro/tonę w 2006 r. do 26,3 euro/tonę w 2010 r.). Wprowadzono system raportowania cen cukru oraz rozwiązanie polegające na prywatnym magazynowaniu cukru w przypadku spadku ceny rynkowej poniżej ceny referencyjnej. W czasie trwania reformy plantatorom rezygnującym z produkcji buraków cukrowych przysługiwała rekompensata poniesionych strat w postaci „oddzielnej płatności z tytułu cukru”. Ponadto udzielano pomocy restrukturyzacyjnej tym producentom, którzy zrezygnowali z produkcji cukru.

Założono, że w wyniku reformy zwiększy się konkurencyjność unijnego rynku cukru wobec rynku globalnego, a efekt ten osiągnięty zostanie głównie poprzez koncentrację produkcji cukru w większych i bardziej wydajnych przedsiębiorstwach na obszarach o najlepszych warunkach uprawy buraków cukrowych (Burrell 2014). Zmiany te przyczynią się do zwiększenia długości kampanii cukrowniczej, a co za tym idzie wzrostu wydajności produkcji cukru w przeliczeniu na 1 ha uprawy buraków oraz podniesienia średniej wartości produkcji w przeliczeniu na jedną cukrownię. Należy zaznaczyć, że oprócz krajów nieprowadzących produkcji cukru (Cypr, Malta, Estonia) oraz tych, które w wyniku w/w reformy zrezygnowały z jego produkcji (Bułgaria, Łotwa, Irlandia, Portugalia kontynentalna i Słowenia), w ramach pozostałych 18 członków UE - w warunkach ograniczenia skali produkcji - proces koncentracji objął przede wszystkim kraje „pasa buraczanego” (por. tab. 1). 
Tabela 1. Kraje „pasa buraczanego” Unii Europejskiej - wybrane elementy określające reformy rynku cukru UE

\begin{tabular}{|c|c|c|c|c|c|c|c|c|c|}
\hline \multirow{2}{*}{ Państwo } & \multicolumn{3}{|c|}{$\begin{array}{c}\text { Roczne kwoty produkcji } \\
\text { cukru w tys. ton cukru } \\
\text { białego }\end{array}$} & \multicolumn{3}{|c|}{$\begin{array}{l}\text { Plony buraków cukrowych } \\
\qquad \text { w t/ha }\end{array}$} & \multicolumn{3}{|c|}{ Liczba cukrowni w szt. } \\
\hline & $\begin{array}{c}2006 / \\
2007\end{array}$ & $\begin{array}{c}2010 / \\
2011\end{array}$ & $\begin{array}{c}\text { zmiana } \\
\%\end{array}$ & 2006 & 2010 & $\begin{array}{c}\text { zmiana } \\
\%\end{array}$ & $\begin{array}{c}2005 / \\
2006\end{array}$ & $\begin{array}{c}2009 / \\
2010\end{array}$ & $\begin{array}{c}\text { zmiana } \\
\%\end{array}$ \\
\hline Wielka Brytania & 1138,6 & 1056,5 & $-7,2$ & 56,9 & 55,3 & $-2,8$ & 6 & 4 & -33 \\
\hline Francja & 3288,7 & 3004,8 & $-8,6$ & 78,8 & 83,1 & 5,5 & 30 & 25 & -17 \\
\hline Belgia & 819,8 & 676,2 & $-17,5$ & b.d. & 82,7 & - & 6 & 3 & -50 \\
\hline Holandia & 864,6 & 804,9 & $-6,9$ & 66,0 & 74,8 & 13,4 & 5 & 2 & -60 \\
\hline Niemcy & 3416,9 & 2898,3 & $-15,2$ & 57,7 & 64,4 & 11,6 & 26 & 20 & -23 \\
\hline Polska & 1671,9 & 1405,6 & $-15,9$ & 43,8 & 48,3 & 10,3 & 36 & 18 & -50 \\
\hline
\end{tabular}

Źródło: opracowanie własne na podstawie danych Eurostat 2006-2011 oraz Sugar Engineers' Library.

Według raportów Komisji Europejskiej - zgodnie z założeniem reformy - na rynku mają pozostać plantatorzy, którzy wykazują najwyższe plony buraków cukrowych oraz cukrownie o najwyższej wydajności (Post-Reform European Union Sugar... 2011; Evolution of the sugarimports... 2013). Sytuacja na rynku cukru w poszczególnych państwach „pasa buraczanego" jest zróżnicowana. We wszystkich krajach, w tym także w Polsce, spadły roczne kwoty produkcji cukru. Najmniejszy jednak spadek odnotowano w Holandii, Wielkiej Brytanii i Francji. Zauważono pozytywną zmianę wzrostu plonów buraków cukrowych w badanych latach, jednak poziom wyjściowy plonów buraków w Polsce był znacznie niższy (43 t/ha) niż średnie plony w pięciu pozostałych krajach wydzielonego regionu (65 t/ha) i w badanych latach zwiększył się średnio 10 pkt we wszystkich krajach (por. tab. 1).

Obecnie najwięcej cukrowni funkcjonuje we Francji, Niemczech i w Polsce, przy czym podczas reformy w Polsce zamknięto ich najwięcej, bo aż 50\%.

Zastanawia zatem, czy polscy plantatorzy i zlokalizowane na terenie naszego kraju cukrownie są konkurencyjne na rynku unijnym. Czy przyszła reforma rynku cukru Unii Europejskiej (od września 2017 r.) nie zmarginalizuje polskiego cukrownictwa w gospodarce UE?

\section{Produkcja buraków cukrowych w Polsce}

Na podstawie danych z PSR 2002 i 2010 przeanalizowano stan oraz tempo i kierunki zmian w powierzchni upraw buraków cukrowych. Przed 2004 rokiem, kiedy polskie rolnictwo nie funkcjonowało jeszcze w ramach Wspólnej Polityki Rolnej, produkcja i przetwórstwo buraków cukrowych nie podlegało kwotowaniu. W tym czasie na terenie całego kraju funkcjonowało 69 cukrowni, podczas gdy w 2006 r. już tylko 36. Trzeba jednak pamiętać, że restrukturyzacja i prywatyzacja przemysłu cukrowniczego następowała od początku transformacji gospodarczej w Polsce.

Uprawa buraków cukrowych i ich przetwórstwo ma w Polsce wieloletnią tradycję. Badania dotyczące zróżnicowania przestrzennego wskazują, że koncentracja upraw związana jest z obszarami o najlepszej jakości rolniczej przestrzeni produkcyjnej oraz stosunkowo wysokiej kulturze rolnej (znaczące wymogi agrotechniczne: duże nakłady pracy - zwłasz- 
cza uprzedmiotowionej, obfite nawożenie, staranna uprawa i pielęgnacja) oraz przede wszystkim bliskością lokalizacji cukrowni (por. Bański 2007, s. 144-146; Głębocki 2007, s. 235-237; Kulikowski 2013, s. 39-40; Stola i Szczęsny 1976, s. 90-91). Oddziaływanie w/w czynników potwierdziła analiza wyników PSR 2010. W 2010 r. powierzchnia uprawy buraka cukrowego wynosiła ponad 206 tys. ha, co stanowiło 2\% ogólnej powierzchni zasiewów. Odsetek ten wahał się w układzie województw od prawie braku zasiewów w województwie podlaskim do ponad 4,3\% w kujawsko-pomorskim (tab. 2). Uprawa buraków cukrowych charakteryzuje się dużą koncentracją przestrzenną - blisko 75\% jej krajowej powierzchni jest położona w pięciu województwach: dolnośląskim, kujawsko-pomorskim, lubelskim, opolskim i wielkopolskim (Głębocki 2014, s. 222-224).

Rejony koncentracji uprawy buraków cukrowych (ponad 5\% zasiewów) występują na obszarach o korzystnych warunkach przyrodniczych (Kujawy, Ziemia Chełmińska, Lubelszczyzna oraz południowa część województw wielkopolskiego i opolskiego - por. ryc. 1). Zależność tę potwierdza także duża różnica udziału buraków cukrowych w ogólnej powierzchni zasiewów między powiatami o niekorzystnych $(0,1 \%)$ i korzystnych warunkach przyrodniczych (3,8\%). Wysokie wartości tego odsetka na ziemiach dawnego zaboru pruskiego i w granicach Polski w okresie międzywojennym (3\%) oraz w powiatach cechujących się wysokim poziomem rolnictwa $(3,2 \%)$ wskazują na dużą rangę czynnika tradycji uprawy i poziomu kultury rolnej, tym bardziej, że na terenach tych zlokalizowano największą liczbę cukrowni. Wykazano, że około 80\% powierzchni upraw buraków cukrowych w Polsce skoncentrowane było na terenach powiatów o wysokim poziomie rolnictwa.

Analiza porównawcza PSR 2002 i 2010 wykazała, że w okresie tym powierzchnia uprawy buraków cukrowych w Polsce zmniejszyła się o prawie 100 tys. ha - wskaźnik zmian, przyjmując za 100 pkt areał w 2002 r., wynosił 68 pkt. Zmniejszenie powierzchni uprawy wiązało się ściśle ze spadkiem liczby cukrowni (z 69 w 2002 r. do 18 w 2010 r.). W 2002 r. były tylko dwa województwa, w których nie zlokalizowano żadnej cukrowni (małopolskie i warmińsko-mazurskie), natomiast w 2010 r. takich regionów było sześć (por. tab. 2). Zmiany te miały najbardziej spektakularny charakter w województwie podlaskim - wskaźnik 4 pkt - gdzie zamknięcie w 2008 r. jedynej w regionie cukrowni w Łapach uruchomiło proces dynamicznego zmniejszania się powierzchni zasiewu buraków cukrowych (z 6,5 tys. ha w 2002 r. do zaledwie 0,3 tys. ha w 2010 r.). Poniżej 50\% spadek powierzchni zasiewu buraków cukrowych miał także miejsce w województwie lubuskim. W regionie tym zamknięto jedyną cukrownię we Wschowie, jednakże część plantatorów przejęły cukrownie z sąsiednich regionów.

Przyjęcie w ramach reformy rynku cukru UE kryterium ograniczania najmniej wydajnej produkcji buraków cukrowych spowodowało, że w warunkach ogólnego spadku powierzchni upraw tendencja ta najsłabiej zaznaczyła się w powiatach charakteryzujących się korzystnymi warunkami przyrodniczymi (69 pkt), silniej zurbanizowanych (podregiony miejskie 79 pkt), położonych w granicach dawnego zaboru pruskiego i na terenach Polski w okresie międzywojennym (79 pkt), wyróżniających się wysokim poziomem rolnictwa (71 pkt.; por. tab. 1).

Oddziaływanie reformy rynku cukru UE zaznaczyło się także poprzez zmniejszenie liczby plantatorów (ubyło blisko 50 tys. gospodarstw - od 101,3 tys. w 2002 r. do 51,3 tys. w 2010 r.) oraz do podniesienia o 1 ha przeciętnej powierzchni uprawy buraków cukrowych (od 3 ha w 2002 r. do 4 ha w 2010 r.; obliczenia wg Banku Danych Lokalnych GUS). 
Tabela 2. Zmiany uprawy buraków cukrowych i liczby cukrowni w Polsce w latach 2002-2010

\begin{tabular}{|c|c|c|c|c|c|c|c|c|c|}
\hline \multirow{4}{*}{ Wyszczególnienie } & \multirow{2}{*}{\multicolumn{2}{|c|}{ Cukrownie }} & \multicolumn{5}{|c|}{$\begin{array}{l}\text { Powierzchnia upraw buraków } \\
\text { cukrowych }\end{array}$} & \multirow{2}{*}{\multicolumn{2}{|c|}{$\begin{array}{l}\text { Powierzchnia } \\
\text { objęta płatno- } \\
\text { ścią cukrową } \\
\text { UE w } 2010 \text { r. }\end{array}$}} \\
\hline & & & \multicolumn{4}{|c|}{ Stan } & \multirow{3}{*}{$\begin{array}{c}\begin{array}{c}\text { zmia- } \\
\text { ny ha }\end{array} \\
2002- \\
2010\end{array}$} & & \\
\hline & \multirow{2}{*}{$\begin{array}{l}2002 \\
\text { liczba }\end{array}$} & \multirow{2}{*}{$\begin{array}{l}2010 \\
\text { liczba }\end{array}$} & \multicolumn{2}{|c|}{$2002 r$} & \multicolumn{2}{|c|}{2010 r. } & & \multirow{2}{*}{$\begin{array}{l}\text { tys. } \\
\text { ha }\end{array}$} & \multirow{2}{*}{ 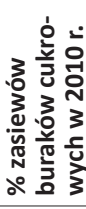 } \\
\hline & & & $\begin{array}{l}\text { tys. } \\
\text { ha }\end{array}$ & $\%$ & $\begin{array}{l}\text { tys. } \\
\text { ha }\end{array}$ & $\%$ & & & \\
\hline POLSKA & 69 & 18 & 303,0 & 2,8 & 206,4 & 2,0 & 68 & 248,2 & 120 \\
\hline \multicolumn{10}{|c|}{ województwa } \\
\hline Dolnośląskie & 11 & 2 & 29,7 & 4,2 & 19,1 & 2,7 & 64 & 25,5 & 134 \\
\hline Kujawsko-pomorskie & 11 & 3 & 54,0 & 5,9 & 38,4 & 4,3 & 71 & 42,6 & 111 \\
\hline Lubelskie & 9 & 2 & 46,1 & 4,2 & 33,7 & 3,3 & 73 & 35,4 & 105 \\
\hline Lubuskie & 1 & 0 & 2,3 & 0,9 & 0,9 & 0,3 & 41 & 2,2 & 234 \\
\hline Łódzkie & 4 & 1 & 10,8 & 1,4 & 6,7 & 0,9 & 62 & 8,2 & 124 \\
\hline Małopolskie * & - & - & 1,8 & 0,5 & 1,6 & 0,5 & 89 & 1,8 & 114 \\
\hline Mazowieckie & 4 & 1 & 23,0 & 1,8 & 11,8 & 1,0 & 51 & 19,9 & 169 \\
\hline Opolskie & 4 & 1 & 23,1 & 5,1 & 14,5 & 3,2 & 63 & 19,9 & 138 \\
\hline Podkarpackie * & 2 & 2 & 6,6 & 1,8 & 4,6 & 1,5 & 70 & 5,4 & 118 \\
\hline Podlaskie & 1 & 0 & 6,5 & 1,0 & 0,3 & 0,0 & 4 & 5,1 & 1849 \\
\hline Pomorskie & 4 & 1 & 13,7 & 2,5 & 9,9 & 1,7 & 72 & 10,8 & 109 \\
\hline Śląskie * & 2 & 0 & 2,9 & 1,1 & 1,7 & 0,6 & 58 & 2,1 & 124 \\
\hline Świętokrzyskie & 3 & 0 & 9,7 & 2,6 & 5,1 & 1,6 & 53 & 7,9 & 155 \\
\hline Warmińsko-mazurskie & - & - & 5,1 & 0,9 & 3,4 & 0,6 & 66 & 4,0 & 117 \\
\hline Wielkopolskie & 10 & 4 & 54,0 & 3,7 & 42,8 & 2,9 & 79 & 46,5 & 109 \\
\hline Zachodniopomorskie & 3 & 1 & 13,6 & 2,3 & 12,1 & 1,8 & 89 & 10,8 & 89 \\
\hline \multicolumn{10}{|c|}{ uwarunkowania przyrodnicze } \\
\hline Niekorzystne warunki & 1 & 0 & 1,3 & 0,2 & 0,8 & 0,1 & 63 & 0,8 & 97 \\
\hline Przeciętne warunki & 25 & 7 & 128,8 & 1,9 & 85,7 & 1,3 & 67 & 105,2 & 123 \\
\hline Korzystne warunki & 43 & 11 & 172,9 & 5,3 & 119,9 & 3,8 & 69 & 142,2 & 119 \\
\hline \multicolumn{10}{|c|}{ uwarunkowania urbanizacyjne } \\
\hline Podregiony wiejskie & 43 & 12 & 220,3 & 3,2 & 148,4 & 2,3 & 67 & 180,6 & 122 \\
\hline Podregiony przejściowe & 18 & 4 & 55,0 & 1,9 & 36,1 & 1,2 & 66 & 44,8 & 124 \\
\hline Podregiony miejskie & 8 & 2 & 27,8 & 2,9 & 21,9 & 2,3 & 79 & 22,8 & 104 \\
\hline \multicolumn{10}{|c|}{ uwarunkowania historyczne } \\
\hline Dawny zabór austriacki & 3 & 1 & 7,9 & 1,1 & 5,8 & 1,1 & 73 & 6,7 & 116 \\
\hline Dawny zabór pruski & 18 & 7 & 81,6 & 3,8 & 64,6 & 3,0 & 79 & 68,2 & 106 \\
\hline Dawny zabór rosyjski & 25 & 4 & 126,7 & 2,5 & 76,8 & 1,7 & 61 & 100,5 & 131 \\
\hline Ziemie odzyskane & 23 & 6 & 86,8 & 2,9 & 59,2 & 1,9 & 68 & 72,8 & 123 \\
\hline \multicolumn{10}{|c|}{ poziom rolnictwa } \\
\hline Niski poziom & 3 & 1 & 8,7 & 0,6 & 4,9 & 0,4 & 57 & 6,7 & 136 \\
\hline Średni poziom & 12 & 0 & 53,5 & 1,4 & 30,8 & 0,8 & 58 & 39,1 & 127 \\
\hline Wysoki poziom & 54 & 17 & 240,9 & 4,4 & 170,7 & 3,2 & 71 & 202,4 & 119 \\
\hline
\end{tabular}

Źródło: opracowanie własne na podstawie danych GUS (wyniki PSR 2002 i PSR 2010) oraz informacji ARiMR (2010 r. - powierzchnia objęta płatnością cukrową) 

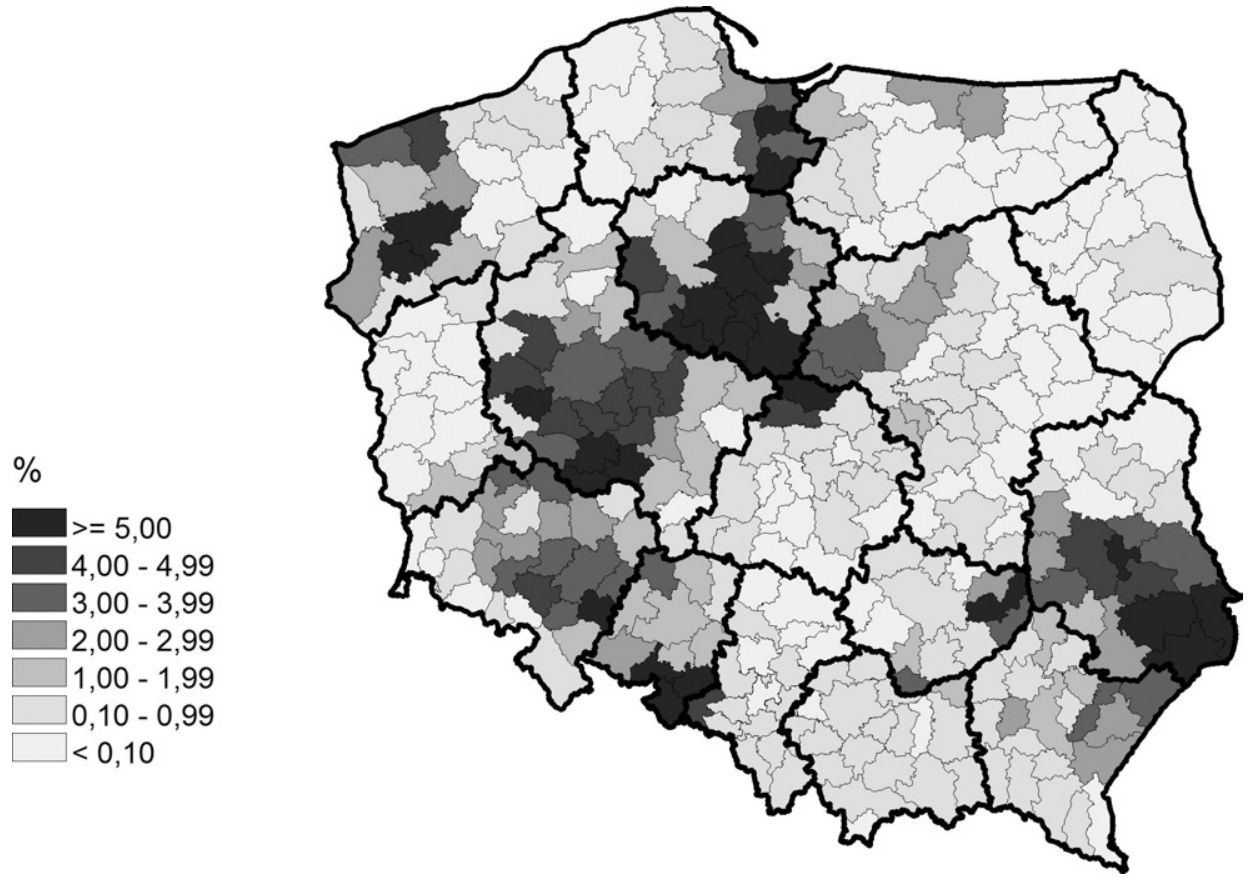

Ryc. 1. Udział buraków cukrowych w powierzchni zasiewów w 2010 r. Źródło: opracowanie własne na podstawie wyników PSR 2010 Share of sugar beet in the total crop area in 2010. Source: own study based on the results of NAC 2010

\section{Oddziaływanie reformy runku cukru na produkcję buraków cukrowych}

Jak już wspomniano, od sezonu 2006/2007 wprowadzono w państwach Unii Europejskiej pierwszy etap reformy rynku cukru, który miał być realizowany przez cztery lata. Jednym z najważniejszych instrumentów tej reformy były płatności cukrowe wypłacane rolnikom, którzy mając wcześniej zawartą umowę z producentem na dostawy buraków cukrowych, zrzekli się przyznanych kwot i zaprzestali uprawy. W Polsce stawki tak określonej rekompensaty finansowej wahały się od 33,94 zł (2006 r.) do 50,45 zł (2010 r.) za 1 tonę buraków cukrowych (por. Rudnicki 2014, s. 102). Zagadnienie to przedstawiono na przykładzie stanu w 2010 r., wprowadzając do analizy wskaźnik ilustrujący udział powierzchni objętej płatnością cukrową UE (wg ARiMR) w ogólnej powierzchni zasiewów buraków cukrowych (wg PSR). Tak określony wskaźnik oceny przestrzennego oddziaływania reformy rynku cukru UE wynosił średnio w Polsce 120\% (powierzchnia płatności cukrowej była wyższa o 41,8 tys. ha od areału zasiewu), a według województw wahał się on od 89\% w zachodniopomorskim do $1849 \%$ w podlaskim (por. tab. 2). Analiza rozkładu przestrzennego tego wskaźnika w układzie powiatów pozwala zidentyfikować obszary problemowe powstałe w wyniku reformy rynku cukru, cechujące się szczególnie silnym ubytkiem uprawy buraków cukrowych, na ogół wynikającym z likwidacji cukrowni (por. ryc. 2). 
$\%$

$>=200,0$

$150,0-199,9$

$100,0-149,9$

$50,0-99,9$

$<50,0$

brak zjawiska/no occurrence

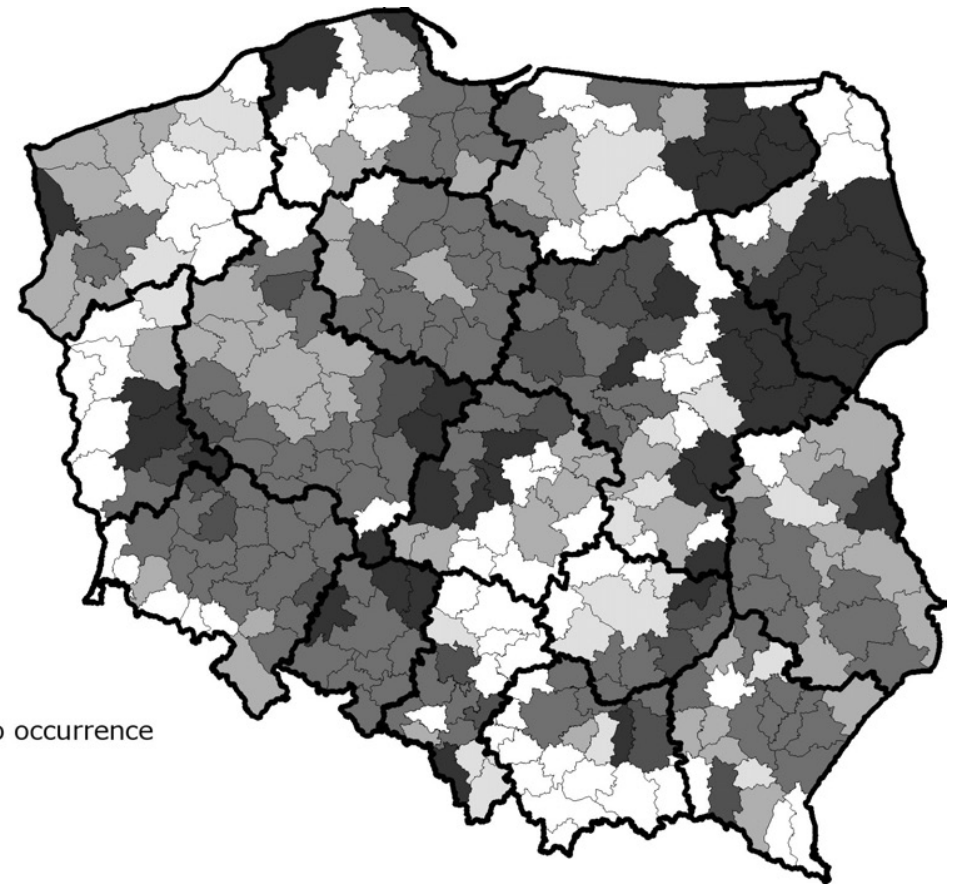

Ryc. 2. Udział powierzchni objętej płatnością cukrową w ogólnej powierzchni zasiewów buraków cukrowych w 2010 r.

Źródło: opracowanie własne na podstawie danych GUS (wyniki PSR 2010) i ARiMR (płatność cukrowa).

Share of area covered by sugar payment in the total sugar beet crop area in 2010

Sources: own study based on data by the CSO (NAC 2010) and the ARMA (sugar payment).

Jak wynika z analizy ryciny 2, w 23 powiatach w Polsce nie zanotowano pozyskiwania płatności cukrowych, ze względu na to, że nie zanotowano tam wcześniej ich uprawy. Sytuacja ta miała miejsce na obszarze Pomorza Środkowego, zachodniej części województwa lubuskiego, zachodniej części Pojezierza Mazurskiego, w powiatach granicznych województw łódzkiego, świętokrzyskiego i śląskiego oraz w południowej części województwa małopolskiego. Z drugiej strony wysoki udział płatności cukrowych związany był z rezygnacją z produkcji najmniej efektywnych producentów, często prowadzących uprawę o małym areale lub w sąsiedztwie zlikwidowanych cukrowni. Największy udział przyznanych w 2010 r. płatności zanotowano w powiatach województwa podlaskiego i wschodniej części mazowieckiego, gdzie zamknięto jedyną tam funkcjonującą cukrownię w Łapach, w powiatach południowowschodnich województwa świętokrzyskiego, gdzie zamknięto cukrownię w Częstocicach. Relatywnie niski udział płatności cukrowych zaobserwowano także w województwach kujawsko-pomorskim (111\%), lubelskim (105\%) i wielkopolskim (109\%), które charakteryzowały się największym - chociaż spadającym - udziałem powierzchni zasiewów buraków cukrowych w stosunku do ogółu zasiewów. Należy zaznaczyć, że w województwach tych w latach 2006-2010 również zamknięto 3 cukrownie w kujawsko-pomorskim i lubelskim oraz $1 \mathrm{w}$ wielkopolskim (por. ryc. 3). 


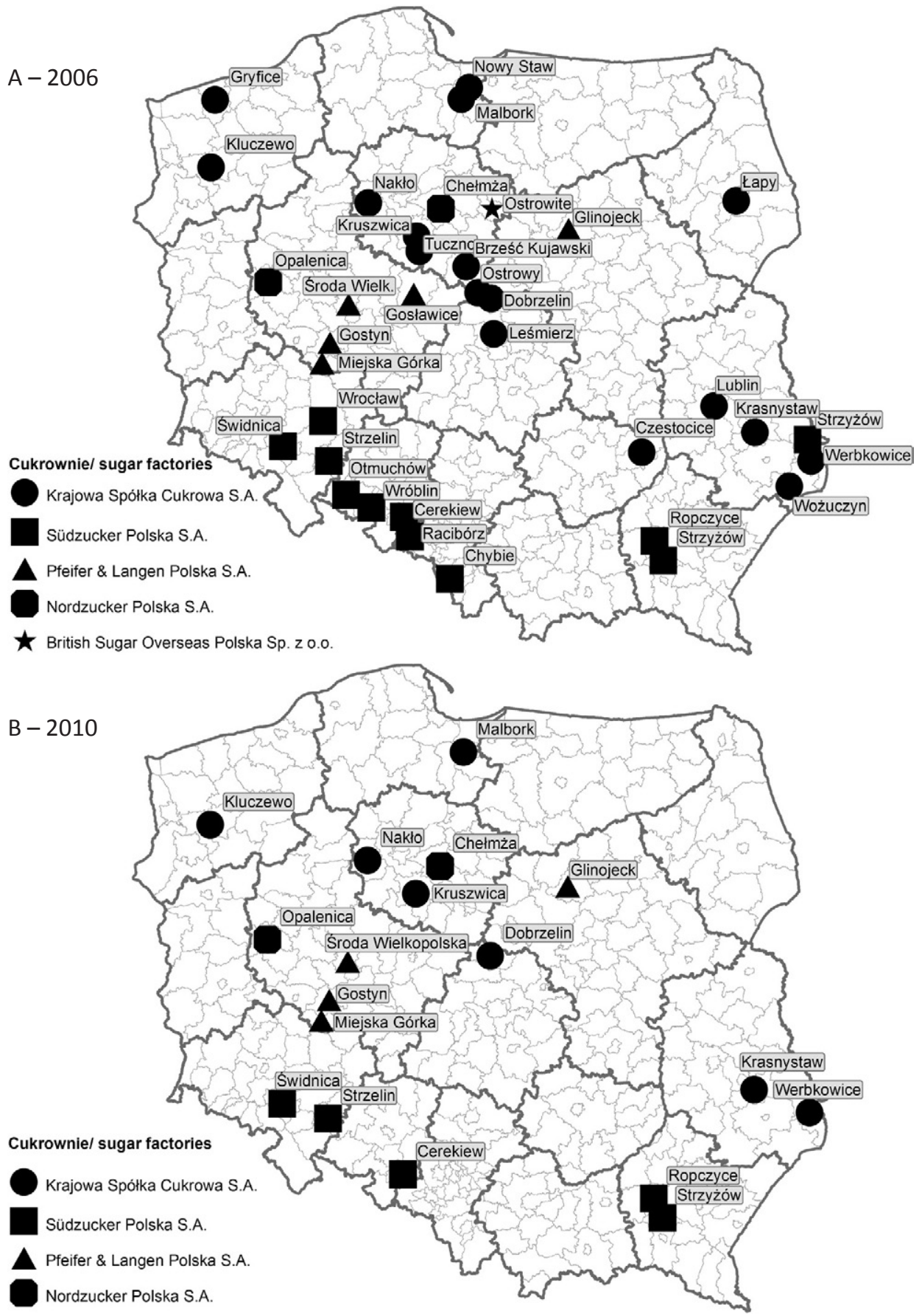

Ryc. 3. Rozmieszczenie i struktura własnościowa cukrowni w Polsce w 2006 i w 2010 r.

Źródło: opracowanie własne na podstawie danych Stowarzyszenia Techników Cukrowników.

Distribution and ownership structure of sugar factories in Poland in 2006 and 2010

Source: own study based on data from the Association of Sugar Technicians. 
Zgodnie z założeniem reformy na rynku mieli pozostać wydajni plantatorzy, zawierający umowy z najbardziej efektywnymi przetwórniami. W czterech dominujących pod tym względem województwach - w latach, które obejmowała reforma - zanotowano również znaczący wzrost plonów buraków cukrowych z 46 t/ha w 2006 r. do 56 t/ha w 2010 r. w kujawsko-pomorskim oraz w dolnośląskim z 42 t/ha do 64 t/h, w lubelskim z 41 t/ha do 55 t/ha oraz wielkopolskim z 43 t/ha do 61 t/ha w 2010 r. Zjawisko to należy uznać za pozytywne, jednak poziom plonowania buraków cukrowych w tych województwach, w porównaniu ze średnim plonem buraków cukrowych w państwach położonych w unijnym „pasie buraczanym”, jest znacznie niższy. Można wiec sądzić, że polscy plantatorzy będą mało konkurencyjni na unijnym rynku cukru.

W ocenie zmian w uprawie buraków cukrowych wykorzystano także hierarchiczną analizę skupień metodą Warda. Wzięto pod uwagę dane w układzie powiatów, dotyczące powierzchni zasiewów buraków cukrowych, jej udziału w powierzchni zasiewów ogółem, a także powierzchnię objętą płatnością cukrową UE w 2010 r. w odniesieniu do powierzchni zasiewów buraków cukrowych. Wykazano, że w połowie odległości wiązania na dendrogramie powstały dwa skupienia. Jedno mniej liczne skupiało powiaty, w których zlokalizowanych było 9 spośród 18 cukrowni pracujących w 2010 r. Na niższym poziomie skupienia (ok. 20\% maksymalnej odległości wiązania), obiekty podzielone zostały na 3 grupy, których wyodrębnienie z reguły zależy od obecności cukrowni na ich terenie. Świadczy o tym fakt, że powiaty, w których funkcjonowały cukrownie, są do siebie statystycznie podobne.

Polska zajmuje trzecie miejsce w Unii Europejskiej pod względem liczby funkcjonujących cukrowni, za Francją i Niemcami. Jednak w naszym kraju zamknięto ich najwięcej. Od początku trwania pierwszej unijnej reformy rynku cukru 2006/2007-2010/2011 liczba przetwórni buraków cukrowych spadła w Polsce o połowę. Początkowo w 2006 r. funkcjonowało 36 przetwórni, jednak nie wszystkie wykorzystywały swoje pełne moce produkcyjne. W sezonie 2010/2011 funkcjonowało już tylko 18 cukrowni (por. ryc. 3). Najwięcej było w województwie wielkopolskim (4) i kujawsko-pomorskim (3). W województwach dolnośląskim, lubelskim i podkarpackim były po dwie cukrownie. W pozostałych pięciu województwach było po jednej, natomiast w sześciu nie było żadnej (por. ryc. 3B).

W polskim cukrownictwie już od połowy lat 90. funkcjonowało czterech inwestorów zagranicznych, trzech niemieckich i jeden brytyjski (Niemczak 2008). Zlokalizowane na terenie Polski przetwórnie buraków cukrowych należały w 2006 r. do pięciu, natomiast w 2010 r. do czterech koncernów (por ryc. 3A i 3B). Największym inwestorem była jednak Krajowa Spółka Cukrowa S.A, będąca właścicielem siedmiu cukrowni, kolejne pięć należało do koncernu Südzucker Polska SA, właścicielem czterech cukrowni była firma z niemieckim kapitałem Pfeifer\&Langen Polska SA, a dwie pozostałe należały do koncernu Nordzucker Polska SA. W badanych latach najwięcej zostało zamkniętych cukrowni należących do Krajowej Spółki Cukrowej (10) oraz do koncernu Südzucker (6). 


\section{Podsumowanie}

Reforma unijnego rynku cukru wpłynęła na zmniejszenie powierzchni upraw buraków cukrowych w Polsce (w latach 2002-2010 ubyło blisko 100 tys. ha), przy jednoczesnym znaczącym wzroście plonów (w latach 2006-2010 plony wzrosły o 4,5q/1 ha) i przeciętnego areału plantacji (w latach 2002-2010 nastąpił wzrost o 1 ha). Przyczyniło się to do koncentracji upraw na obszarach o najkorzystniejszych warunkach przyrodniczych, cechujących się wysokim i historycznie ukształtowanym poziomem rolnictwa. Pierwszy etap reformy (lata 2006-2010) spowodował także spadek liczby cukrowni oraz podział rynku cukru w Polsce między cztery duże koncerny cukrownicze.

Sektor cukrowniczy w Unii Europejskiej od 30 września 2017 r. będzie podlegał kolejnej reformie, w wyniku której zostaną zniesione kwoty produkcji cukru oraz ceny minimalne buraków cukrowych. Całkowita produkcja unijna będzie mogła być udostępniona na jej rynku wewnętrznym. Pozostaną ceny referencyjne cukru oraz system raportowania cen, które posłużą tylko do obserwacji rynku. Zniesiony zostanie również limit eksportu na rynki światowe, przy zachowaniu wcześniej uzgodnionego w ramach porozumień o wolnych handlu, importu cukru trzcinowego na rynek unijny. Wprowadzony zostanie nowy system kontraktacji, kiedy to plantator będzie podpisywał kontrakt uprawowy na dwa lata przed sprzedażą cukru. Nie jest pewne, czy zostanie utrzymany i jaki będzie poziom ceł na cukier importowany od Unii Europejskiej (The EU Sugar Market... 2014).

Trudno przewidzieć, jak nadchodząca reforma wpłynie na polski rynek cukru. Może okazać się, że wprawdzie obszar naszego kraju leży w unijnym „pasie buraczanym”, jednak okres adaptacji działających w Polsce cukrowni do standardów w państwach Europy Zachodniej był zbyt krótki, co może przyczynić się do wzrostu konkurencji na wewnętrznym rynku z bardziej wydajnymi plantatorami i cukrowniami innych krajów UE. Nie bez znaczenia wydaje się również fakt, że większość działających Polsce cukrowni nie jest w polskich rękach.

\section{Literatura}

Bański J., 2007, Geografia rolnictwa Polski, PWE, Warszawa

Burrell A. (red.), 2014, EU sugar policy: A sweet transition after 2015?, European Commission Joint Research Centre, Institute for Prospective Technological Studies, Luxembourg, Publications Office of the European Union.

Evaluation of Common Agricultural Policy measures applied to the sugar sector, 2011, Report - AGROSYNERGIE - December 2011.

Evolution of the sugar imports in the European Union from LDC and ACP countries, 2013, Report from the Commission to the European Parliament and the Council, Brussels, 31.5.2013.

Głębocki B., 2007, Rolnictwo, [w:] H. Rogacki (red.), Geografia społeczno-gospodarcza Polski, Wydawnictwo Naukowe PWN, Warszawa, s. 185-267.

Głębocki B., 2014, Zmiany w strukturze przestrzennej upraw polowych, [w:] B. Głębocki (red.), Zróżnicowanie przestrzenne rolnictwa, Powszechny Spis Rolny 2010, Wyd. GUS, Warszawa, s. 200-252.

Kulikowski R., 2013, Produkcja i towarowość rolnictwa w Polsce. Przemiany i zróżnicowanie przestrzenne po /l wojnie światowej, Prace Geograficzne IGiPZ PAN, 241, Warszawa. 
Niemczak M., 2008, Przemiany struktur polskiego przemysłu cukrowniczego jako efekt procesu restrukturyzacji. Procesy transformacji układów przemysłu na tle zmieniajacego się otoczenia, Prace Komisji Geografii Przemysłu PTG, 10, Warszawa-Kraków.

Post-Reform European Union Sugar - Prospects for the Future, 2011, Global Agricultural Informational Network Raport no. E 60078, 12/21/2011

Racine J.B., Reymond H., 1977, Analiza ilościowa w geografii, PWN, Warszawa.

Rudnicki R., 2014, Przemiany struktury zasiewów w rolnictwie polskim w warunkach oddziaływania instrumentów Wspólnej Polityki Rolnej (lata 2002-2010), [w:] W. Kamińska, K. Heffner (red.), Polityka spójności UE a rozwój obszarów wiejskich: stare problemy i nowe wyzwania, Studia KPZK PAN, t. CLVI, Warszawa, s. 98-128.

Rudnicki R., 2009, Renty strukturalne jako czynnik przemian agrarnych i demograficznych w rolnictwie polskim w latach 2004-2006, Bogucki Wydawnictwo Naukowe, Poznań.

Rudnicki R., 2010, Zróżnicowanie przestrzenne wykorzystania funduszy Unii Europejskiej przez gospodarstwa rolne w Polsce w latach 2004-2006, Seria: Studia i Prace z Geografii i Geologii, 17, Bogucki Wydawnictwo Naukowe, Poznań.

Stola W., Szczęsny R., 1976, Geografia rolnictwa Polski, Wydawnictwa Szkolne i Pedagogiczne, Warszawa.

The EU Sugar Market Post 2017 Market Evaluation Consumption and Statistics Committee, 2014, International Sugar Organization, April 2014.

Ward J.H., 1963, Hierarchical grouping to optimize an objective function, Journal of the American Statistical Association, 58, 301, s. 236-244.

\section{Summary}

The article presents the preliminary results of spatial research on the reform of the EU sugar market carried out in 2006. The issue concerning decline of area planted with sugar beet in Poland in the years 2002-2010 has been analyzed. In the examined years a positive effect of growth yields of sugar beet can be observed. The reform of the sugar market apart from restricting sugar production limits, assumed introduction of sugar payment, which had the effect of limiting the production of raw material. The consequence of this phenomenon was the liquidation of sugar factories, which in many areas acted as a significant employer. As a result of the reform farmers' production profile was forced to change but also population in the labour market had to be re-trained. The existing sugar factories managed by both Polish and German companies have a tendency of accumulating capital. Poland belongs to the so called "Beet-belt" of the EU, namely a group of countries with the greatest potential for sugar production. However, it is not clear how the common market as well as the effects of the subsequent reform to be conducted in 2017 will affect the level of competitiveness of the Polish sugar industry. 